\title{
Ideological Conflict and Isolation in Atwood's The Handmaid's Tale: A Trans-realistic Reading
}

by: Fatma Taher

Fatma.taher@buc.edu.eg

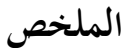

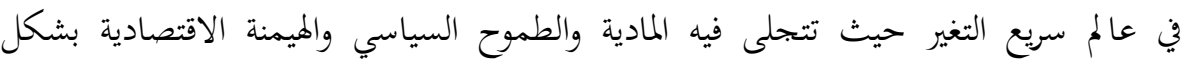

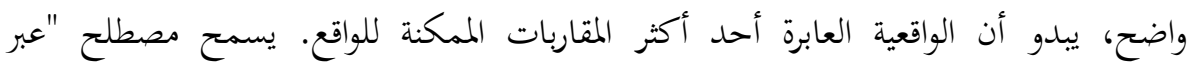

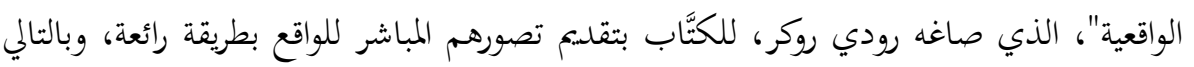

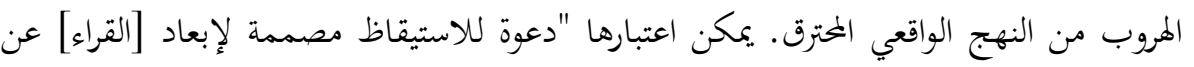

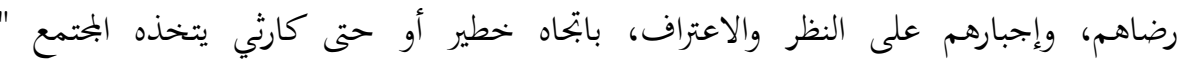
(Loeweinstein 2017).

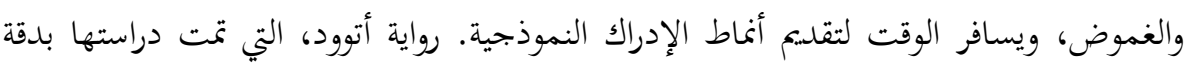

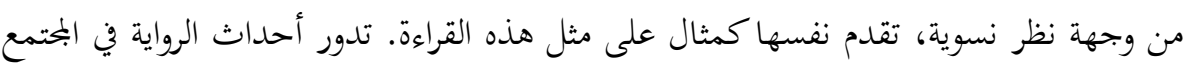

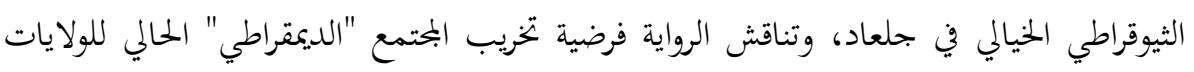

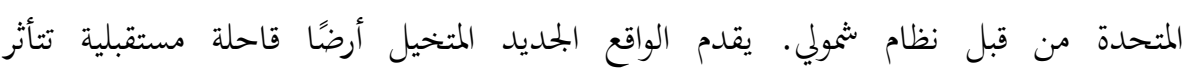
بالإيديولوجيات الحالية.

الهدف من هذه الورقة هو تقديم إعادة قراءة للرواية كنص عبر واقعي يتلاعب بالنصوص

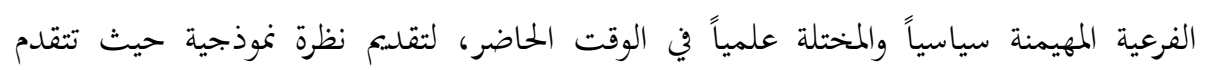
الإنسانية إلى الخلف وإلى الأسفل . [عدل]

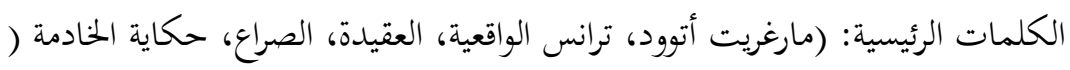




\section{ABSTRACT}

In a rapidly changing world where materialism, political ambition and economic hegemony evidently manifest themselves, trans-realism seems to be one of the most viable approaches to reality. Coined by Rudy Rucker, the term 'trans-realism' allows the writers to present their immediate perception of reality in a fantastic manner, thus escape the all burnt out realistic approach. It can be considered as a "wake-up call designed to shake [the readers] out of [their] complacency, and compel [them] to look at and acknowledge, a certain dangerous or even disastrous direction that society is taking" (Loeweinstein 2017). The writer in this case uses fantasy, alternate world, ambiguity, and time travels to present archetypal modes of perception. Atwood's novel, which has been thoroughly studied from a feminist point of view, presents itself as an example of such a reading. Set in the imaginative theocratic community of Gilead, the narrative discusses the hypothesis of the subversion of the present day 'democratic' society of The United States by a totalitarian regime. The imagined new reality presents a future wasteland affected by current ideologies.

The aim of this paper is to present a re-reading of the narrative as a trans-realistic text that manipulates the politically hegemonic, and scientifically deranged sub-texts of the present, to introduce a model insight where humanity progresses backwards and downwards.

Keywords: (Margaret Atwood, Transrealism, Ideology, conflict, The Handmaid's Tale)

\section{Introduction}

The 1950s witnessed a great validation of realism. Philologists and critics like Balzac, Erich Aurebach and 
Dresier framed the 'representation of reality' within a closely governed social context at a certain moment. Aurebach maintains that in this respect Stendhal is the most important figure: "in so far as the serious realism of modern times cannot represent man otherwise than as embedded in total reality, political, social, and economic, which is concrete and evolving ... Stendhal is its founder" (Qtd in Damian, 31). In that respect, the political situation, the social hierarchy or stratification, and the economic status combine to represent the 'reality' of what Man is. Therefore, they should be illustrated and should crystalize in any work that presents Man.

During the $20^{\text {th }}$ century, critics like Fredrich Jamesonessentially a realist- theorized for postmodernism in his book Postmodernism or the Cultural Logic of Late Capitalism (1991) where he criticizes the dominance of a certain social strata or order and promotes for diversity of representation. Thus, rather than complying with the simple representation of reality at a certain moment of history, postmodernists encouraged a more detailed critical reading and writing that crosses the credible representation or impersonation, in order to interrogate the various small details that make up our entire life. This immense tendency to scrutinize such tiny components persisted till date, to the extent that some are calling for a post-postmodern movement that might extend over to cover all the literary production, in search for the hidden ideological, logical and genderdized dimensions and binaries.

Under this great umbrella of postmodernism that is still functioning to date, variant trends such as magic-realism and Science Fiction flourished. The most recent of those is transrealism, which is a blend of Science Fiction and Realism, given the above fact that the latter, in its traditional 
sense, had become inadequate for representing the chaotic postmodern world. ${ }^{1}$

Transrealism is a term coined by mathematician and SciFi novel writer Rudy Rucker in the eighties of the past century in an attempt to answer the question 'what would come after postmodernism?' It was in 1983 that he compiled the 'Transrealism Manifesto', maintaining that "transrealism is the only valid approach to literature at this point in history. The transrealist writer writes about immediate perceptions in a fantastic way... (in addition) any literature which is not about actual reality is weak." (Rucker, 1983, p.82). "[T] his point of history" is definitely the apocalyptic world where reality exceeds the darkest imagination. $^{2}$

Rucker then furthers this definition in his paper "Seek the Gnarl" (2005), where he provides four main mechanisms of which he believes transrealistic literature consists. First, the subject matter, which should allow for more possibilities for the characters involved and the situations discussed. In this respect he concludes that Science Fiction and magic realism may contain fabulations in literary style and transcendence in technique, while transrealism combines realism and transcendence, with a highly complex subject matter. Second, the plot and structure which according to Rucker vary on a scale of four levels; the lowest being "the standardized plots", and the highest "no large-scale plot at all". In the middle lies transrealistic writings with "unpredictable plots", where the "the last chapter is ... unpredictable from the contents of the first chapter." (15) This is due to the ambiguous and different from the traditional pattern of the linear, chronological plot. Thus, transrealism features a plot that "creates unpredictable situations that the author tweaks so as to express subtexts and subtle mental state" (9). The third mechanism is thought experiment. He believes that 
transrealism occupies a slot where it presents "surprising and creative thought experiment ...rigorously working out the consequences of crazy ideas." (10) Therefore, the most trivial changes to reality have easily predictable consequences" (17). Finally, Rucker maintains that transrealism and transrealistic literature satirizes the society and the social constructs, in order to "force-growing social trends into completely mad yet rigorously logical environments" (19). The above-mentioned mechanisms can be considered as distinguishing features for any literary work that claims to be a transrealistic narrative. Opposite to Science Fiction, transrealism depends mainly on reality and realistic representations rather than on imagination or fantasy alone.

Transrealism is likewise described as a "fictional style associated with realist streams with the most successive display of plot, and with another position of the story subject."(Nardina 72) In this way it challenges settled reality through the representation of fantastical worlds. The author would then use tools of fantasy writing to treat the social, political or ethical problems in real life. So, the narrative, narration and writing practice mixes science fiction and realism to present the author's immediate perception, since "fantasy holds a distorting but revealing mirror up to our present lives" (Maso 8) ${ }^{3}$. Tools like timetravel, alternate worlds, flight are used symbolically as Rucker states: "time travel is memory, flight is enlightenment, and alternate worlds symbolize the great variety of individual world views" (Rucker 1983, p.1). By mixing these 'trans' tools with 'realism', which is one of the most important defining characteristics of any literary work, the author attempts to understand, analyze, and deal with reality, then reach a higher understanding wherein a better life is embedded. 
Contrary to Science Fiction, the transrealist protagonist is not a 'bigger than life' character or a super-person, he/she is a "neurotic and ineffectual as we each know ourselves to be." (Rucker, 1983, p.2) This would be another realistic aspect of transrealism that helps the readers identify with those protagonists and relate to the fantastical worlds, or the 'trans' aspect.

On a different level, transrealism can be considered as one of the many cross-genre fictions like magic-realism, or like blending the different components of dystopian literature and history, or even science fiction with horror as Milena Skobov maintains (Skobov, 2018). It stands as a new literary movement that mixes the real with SF or the surreal. The natural outcome of a world loaded with "accelerating and monumentally disruptive changes" (Brodreick 2005, p.24) that deals with the horrible realization of this present and of the real political, economic and social threats. It can also be considered as the natural outcome of suppression and the incapability of selfexpression in a world that witnesses epistemic crisis. This is what Rudy Rucker refers to as "trying to treat not only the immediate reality, but also the higher reality in which life is embedded" $(2005,2)$. It tries to produce a new content in a different way, "a mode where the 'once upon a time' becomes an escape, and where the hallucinating representation becomes a warning." (Broderick, 2005, p.32). The anti-authoritarian, populist nature of such a narrative entails sympathy, empathy and identification with the suppressed.

The main aim of this paper is to present a re-reading of Margaret Atwood's novel The Handmaid's Tale, as a transrealistic narrative that uses all the featuring elements of Trans-realism to convey her preoccupation -as is also manifest in many of her works- with the call for social change against the collective injustice practiced in the 
present day world. ${ }^{4}$ In other words, how does the 'new' trend help Atwood illustrate and highlight the ideological conflict in the narrative? And how does it intesify the sense of isolation suffered by the protagonist?

\section{The Handmaid's Tale}

Margaret Atwood's novel, The Handmaid's Tale, usually discussed as a feminist dystopia, is reckoned as an example of transrealism as a $21^{\text {st }}$ century literary trend. With reference to the narrative as a feminist novel, Atwood comments: "The Handmaid's Tale" a "feminist" novel? If you mean an ideological tract in which all women are angels and/or so victimized they are incapable of moral choice, no. If you mean a novel in which women are human beings with all the variety of character and behavior that implies and are also interesting and important, and what happens to them is crucial to the theme, structure and plot of the book, then yes. In that sense, many books are "feminist."' (New York Times 2017). This commentary is very significant for the research at hand because it illustrates that Atwood's interest in women is part of her interest in humanity at large as much as of the role women play in their communities. The interest in presenting a realistic story and a protagonist who plays a primary role in real life reflects the author's apprehensions which is one crucial element in transrealism.

On the other hand, The Handmaid's Tale has also been considered a dystopian narrative that has always been compared to Orwell's 1984. Ironically enough, the novel was published in the same year. The Handmaid's Tale focuses on physical, spiritual and mental oppression and isolation through the control of human thought under a totalitarian regime. It discusses the representation of the exploitation of human rights at the hands of the regime that is basically fundamentalist (Howells 163). These themes of power structure, societal hierarchy and the manipulation of 
power have been discussed in many studies that either compare the two novels or scrutinize Atwood's narrative individually.

The narrative of The Handmaid's Tale is based on the fictional assumption that the present day 'democratic' society of the United States is taken over by a theocratic regime after a nuclear war that renders most men and women infertile. The protagonist Offred, one of the maids in a protected concentration camp, is offered to the Commander as a surrogate mother since his wife is incapable of childbearing. In this novel Atwood uses the above-mentioned distinguishing elements of transrealism to discuss the grotesque results of present day social, political injustice, as well as the irrational sprint in the nuclear experiments. Most important of these elements is time/time travel.

\section{Time/Time-travel in The Handmaid's Tale:}

Time, as one of the four dimensions that help us weigh the importance of an event as well as measure its consequences stands as a determining factor besides space (the spatio-temporal relationship) to form the setting of any narrative. In this respect, Atwood's novel stands as one of the best examples of St. Augustin's definition of the 'slippery' quality of time. (Augustine 154). Time is used in the narrative as a tool to preserve memory and the past. The Setting, the city of Gilead, frames out a frozen society suspended in the two dimensions of time and space. The curtains of the events are pulled on the fully established community of Gilead, with equivocal, sporadic reference to the protagonist Offred, 'the past', and to the causes the led to the 'present'. It is not until the very last part of the book, the "Historical Notes", that the readers discover the chronology and the time-frame -if there is any- of the narrative. It is through Offred and the members of the 
Gileadean Society that the readers grasp the intercommunal, interpersonal conflicts concerning the 'past' and 'present' ideologies.

Like most transrealistic fiction, The Handmaid's Tale tries to predict the future under the given circumstances. The author's concern about the nuclear weapons' scientific and technological advances, as well as the hegemonic politics of the United States, propels her to transcend realistic representations in an attempt to help the readers shape a non-Gileadean future society: a non-oppressive, war free earth.

Time travel is the main transrealistic technique used by Atwood to present this dystopic, ideologically differing community. Through this technique, Atwood crosses all the 'physical' barriers of time and space. Opposite to most of the dystopian narratives where the readers are informed about the utopian societies through dialogue and arranged events, Atwood envisions the consequences of present day politics through the protagonist's 'past' interaction with the 'democratic' society which enables her to question and interpret 'present' theocratic ideologies enforced on the whole community of Gilead.

The "Historical Notes" at the end of the novel provides a further commentary on the whole experience, as well as on Offred herself, in a manner that guides and redirects the readers' perception of the whole experience. Throughout the narrative, the readers are exclusively dependent on the protagonist's perspective and observations - mostly blurred, confused and unorganized- this results in a purposefully distorted final representation that highlights the author's purpose of warning against present day aggressive, hegemonic politics.

The use of time travel does not only help Atwood imagine the future, it also helps her move freely between the past, the present and the future. The 1990s (the future 
imagined at the time of writing) presents a community that goes backwards to a very ancient era of the secluded past where all the human and financial interactions are based on the instructions of the Old Testament's scriptures. So does the vocabulary: guards and soldiers are called "Angels", instructors are called Aunts, the camps where the handmaids are gathered and trained are called "The Rachel/Leah Centers" and many other examples that relate the community to the B.C era.

Thus, Atwood's free movement in time can be summarized as follows: she wrote the novel in the eighties of the past century, to speak about the nineties, and in her plot she presents a remote past that dates back to the B.C era. Concurrently, the readers realize at the end of the novel that the whole story about the Gileadean community is accidentally discovered, and randomly arranged in the middle of the $22^{\text {nd }}$ century. This latter incident of how the story of the Gileadean history and that of Offred are discovered is another example of the use of time travel. This takes us back to the 'records' that lead to the discovery. Earlier back in the story, in her room of confinement as a surrogate mother, Offred found the "Nolite te bastardes carborundoum" message, which means 'do not let the bustards grind you down', engraved on the floor. This message takes the readers to an even earlier time to know about the story of the woman who wrote it, and at the same time inspires the protagonist that resistance has always existed and should not be abandoned.

This back and forth movement in time enables Atwood to maintain the readers' attention till the appendix of the "Historical Notes on The Handmaid's Tale" where they discovered the origin and sequence of the events. What first seemed as a direct narration of Offred's tragic experience turns out to be the account of a specific era of Gilead's history. Even this is described as "a partial transcript of the 
proceedings of the Twelfth Symposium on Gileadean Studies" (THT, 311) discovered by accident and reconstructed by Professors Pieixoto and Wade from "approximately thirty tape cassettes, of the type that became obsolete in the eighties or nineties with the advent of the compact disc" (THT, 312) and that they "luckily had, several years before, with the aid of [their] excellent resident antiquarian technicians, reconstructed a machine capable of playing such tapes, and [they] immediately set about the painstaking work of transcription" (THT, 313). Thus, the unnumbered tapes, and the inconspicuous recording are chronologically arranged according to the two professors' point of view. They openly comment that: "It was up to Professor Wade and myself to arrange the blocks of speech in the order in which they appeared to go; but as I have said elsewhere, all such arrangements are based on some guesswork and are to be regarded as approximate, pending further research" (THT, 314).

Atwood evidently experiments the concept of time when she creates a technology free community since the impairment caused by scientific and technological innovation is one of her major concerns as shown through Offred's commentary: "the air got too full, once of chemicals, rays, radiation, the water swarmed with toxic molecules, all of that takes years to clean up, and meanwhile they creep into your body, camp in your fatty cells" (THT, 122). Atwood takes the readers back in time when societies were governed by religious instructions, in a way that presents them as the only solution for humanity to survive. In this way, isolation would be the only answer, and the religious purpose of creation- namely to populate the earthwould be the only governing code of conduct that would compensate for the infertility caused by the advance in technology. 


\section{Ideological Conflict in The Handmaid's Tale:}

In his paper "Seek the Gnarl", Rudy Rucker maintains that besides featuring realism and transcendence, transrealistic fiction should also present a higher level of complexity in subject matter, plot, thought experiment and social commentary. In this regard Atwood works scrupulously to adapt this experimental mechanism and technique to a realistic plot that comments on different disturbing issues like the advancement in technology and the nuclear experiments and weapons mentioned above, in addition to other implicit topics like fundamentalism or extremism. Atwood's choice of a theocratic society as an alternative to the materialistic, 'free' society of the United States of America cannot be overlooked as just an alternative. The past few decades have witnessed great controversies, in some incidents rivalry, that turned into terroristic outbreak on a specific religion, people or belief. Therefore, it cannot be a mere coincidence that the democratic regime is taken over by the Puritans (a fundamentalist theocratic regime). This does not only highlight the conflict between the 'sacred' and the 'secular' but stimulates a number of dogmas that subsequently lead to certain social and political measures affecting all the people in Gilead.

For example, the infertility caused by the advancement in technology; radio-active waves of all the domestic appliances, and nuclear radiations, is considered as God's punishment of an exceedingly materialistic world. The fertility decline caused by the toxic environment is referred to women who challenged God's orders and their primary roles as females by disposing of their babies through abortion or choosing to use contraceptives. Therefore, as explained in the novel, "the elite of the regime arrange to have fertile women assigned to them as handmaids... the Biblical precedent is the story of Jacob and his two wives 
Rachel and Leah, and their two handmaids... One man, four women, twelve sons- but the handmaids could not claim the sons" (THT, Introduction, X). Those fertile women get this exceptionally 'sacred' opportunity to repent for such deeds and play their 'divine' role of populating the earth. They should repent for the deeds of the 'past', where women "dressed like sluts" and sex was practiced for pure pleasure. Hence the 'Orientation Centers' formed to re-educate women on their 'duties' toward their community, but most importantly, towards their creator. For God has created them, protected their health and most importantly gave them the 'womb', and one way of thanking Him would be to conceive, and bear children for the commanders of the Republic. Offred comments, "We are for breeding purposes ... we are two-legged wombs, that's all" (THT, 146), they are all taught to "think of [themselves] as seeds" (THT, 28).

All is done under religious slogans. The above is not religion, but a manifestation of manipulating religious instructions for political control, which would, in Atwood's perspective, lead to tyranny:

A group of authoritarian men seize control and attempt to restore an extreme version of patriarchy... the regime uses biblical symbols, as any authoritarian regime... Many totalitarianisms have ruled behind a religious front. It makes the creation of heretics that much easier.... In the book the dominant "religion" is moving to seize doctrinal control, and religious denominations familiar to us are being annihilated. (Introduction XII)

Nonetheless, the narrative summons a crucial question here: how does this theocratic regime manage to impose its ideology on a community that enjoyed unlimited freedom of expression? How did it strengthen its stand and empower itself among people who boasted about their free will? 
To start with, theocracy, by definition, assumes power and authority from a supreme, impassable entity; namely a god or a deity. It assumes that all man-made authorities are incompetent, if not deficient. Therefore, the theocratic regime entitles itself to certain controls under the name of this god or deity. This might go a step further to interpreting the sacred texts or scriptures to suit the welfare of this regime. In this case the subordinates cannot argue against the imposed regulations or law for fear of being considered heretics. The newly established community of Gilead abandons the system of a jurisdiction that adopts a constitution and returns to the commandments of the Holy Scriptures. The theocratic regime extracts different biblical verses out of their context, and enforce them as laws. Thus, all the rights that humanity in general, women in particular, have gained throughout history are abandoned, and more control over the public is obtained. Hence phrases like "blessed are the meek. Blessed are the silent." (100) or "they also serve who only stand and wait." (28) Such verses entail obedience, submission and loyalty to the authority, regardless to the lawful rights of the public. Enslavement and the impregnation of women is legalized through verses like "from each according to her ability; to each according to his needs."(THT, 127) 6 . However, the rule of 'each according to his needs' does not apply for every single man, it only applies for the commanders. Not all the guards are allowed to have a handmaid. Nick, the Commander's driver, who is later on involved in an illicit relationship with Offred, "hasn't been issued a woman, not even one. He doesn't rate: some defect, lack of connections." (THT, 27) On the other hand, those commanders do not practice religion, and they are not required to do so. Fred, the commander to whom Offred is offered, lives a luxurious life, enjoys all that is denied for the rest of the people, 
cheats upon his wife, and has the ability to pronounce his dissatisfaction with many things in society.

Another evident example in the novel is the definition of freedom: "there is more than one freedom, said Aunt Lydia. Freedom to and freedom from. In the days of anarchy, it was freedom to. Now you are given freedom from. Don't underrate it" (THT, 34). This definition leads to more ideological conflict. The protagonist, an oppressed woman herself, finds 'freedom from' more captivating as she walks in the streets, because 'in the time of anarchy' "women were not protected... There were rules, rules that were never spelled out but that every woman knew: don't open your door to a stranger, even if he says he is a police... don't stop on the road to help a motorist pretending to be in trouble. Keep the locks on and keep going. If anyone whistles, don't turn to look. Don't go to laundromat by yourself at night... now we walk along the same street, in red pairs, and no man shouts obscenities at us, speak to us, touches us, no one whistles" (THT, 34). Hence, much as this extreme theocratic regime opposes the 'common' definition of freedom, it still finds grounds to flourish since the 'freedom to' exceeded all the limits of observing other individual's 'freedom'. On the other hand, the whole concept of "freedom from" is very controversial, since it is directly related to the amount and degree of enforcing certain restrictions and laws on the commoners. Another incident in the narrative shows the public's acceptance of unjustified killing, because the guards who erroneously killed an innocent Nun moving close to their camp were "Doing their job, said Cora, keeping us safe. Nothing safer than dead, said Rita." (30) Death by murder becomes legitimate, opposite to all rational, legal or even the commonly endorsed human logic, where the people are dehumanized and treated as insurgents. 
The ideological conflict between the secular and sacred roles extends to affect each and every individual in the community, not only the handmaids. Serena Joy, the commander's wife is all agitated by the conflicting thoughts of what she must do and how her natural instincts and feelings as a woman make her feel. While she has to accept the fact that her husband impregnates another woman "on (her) knees" without objection, she also comes from a time where the different concepts of individuality, self-respect and women's rights prevailed. This conflict is revealed in the first encounter between Serena and Offred when she comments: "so, you are the new one... She did not step aside to let (Offred) in ... she wanted (her) to feel that (she) could not come into the house unless she said so" (THT, 23). Here, none of the two women really concedes to the requirements of her role. Serena, on the one hand belittles Offred and highlights her own superior position, while Offred, who is brainwashed to believe that she is serving the Lord, assumes power since she is, opposite to the former, capable of begetting children. Nevertheless, neither of them pronounces her thought. If it is the instructions of the Holy Scriptures, how could they object!

These conflicting ideas between what is and what should be takes us back to the American society and the American people. The same society which claims peaceful coexistence of all ideologies, ethnicities and religions, also demonizes 'the other', generalizing individual cases to judge a whole entity. This contradiction would, under the narrative's given circumstances, give grounds for manipulation of any kind, but most particularly religious manipulation. The different mechanism of transrealism helped Atwood exceed the representation of the apocalyptic reality to a more peculiar moment that exemplifies her perception of the inevitability of a catastrophic future. The 'trans' aspect of transrealism allowed for transcending 
reality, though it is frightening enough, to a more intense representation of the imagined future.

\section{Ideology, Isolation and Characterization:}

The isolated setting of the narrative; the theocratic community of Gilead, is set in the present-day Cambridge, including Cambridge University, but in the 1990s. The community is chronologically presented in the middle of ideological conflict on the local and international levels. The religiously conservative views and politics of the Gileadean society that are restricted and inclusive to this place, date back to the B.C era as said above, though Gilead is surrounded by Canada and other neighboring countries. Physical isolation is evident in Offred's observation:

We reach the first barrier, which is like the barriers blocking off roadworks, or dug-up sewers: a wooden crisscross painted in yellow and black stripes, a red hexagon which means stop. Near the gateway there are some lanterns, not lit because it isn't night. Above us, I know there are floodlights, attached to the telephone poles, for use in emergencies, and there are men with machine guns in the pillboxes on either side of the road. I don't see the floodlights and the pillboxes, because of the wings around my face." (THT, 28)

This detailed description of one of the shopping trips presents different types of isolating barriers. Besides the physical barrier illustrated through the physical presence of the soldiers, the barricades and the 'yellow and black wooden crisscross', there are two other types of barriers. First, the visual barrier caused by the 'wings' enforced on the handmaids, which restricts their peripheral and upward vision, as much as they restrict perception. Second, the linguistic barrier as shown in the use of color signs instead of words or verbal communication. All these barriers 
significantly isolate not only the protagonist or her peers, but the whole community of Gilead, since men too are not allowed to speak to the handmaids. In the marketplace, the traders and the handmaids communicate non-verbally through 'the tokens'. Offred says: "I take the tokens from Rita's outstretched hand. They have pictures on them, of the things they can be exchanged for: twelve eggs, a piece of cheese, a brown thing that's supposed to be a steak" (THT, 21). Then, later on in the marketplace, "those who've reached the counter hand their tokens across it, to the two men in the Guardian uniforms who stand on the other side. Nobody talks much" (THT, 35). The totalitarian regime manifests its power through prohibiting verbal communication. Dialogue would mean self-expression, which might in the slightest chance invite for resistance. The images on the tokens prohibit reading as well, if the handmaids are not allowed to read anything, how would they have a shopping list?

This secluding policy turns Offred into a neurotic character -one representing characteristic of transrealistic literature. The narrator of the events, the storyteller Offred, passes through extensive mental and psychological struggles in the community where she and other humans, especially women, are trapped, both physically and spiritually. She keeps warning the readers that she is not sure whether what she is telling is a made-up story or an accurate direct description of what is/has really happened. "I would like to believe that this is a story I am telling. I need to believe it... if t's a story I'm telling, then I have control over the ending ... It isn't a story I'm telling. It's also a story I'm telling in my head, as I go along" (49). This contradictory thought, and the confusion it imbues onto the readers, highlights the neurotic nature of the protagonist. The readers here are sometimes unable to disconnect from reality and get more involved in the story surrendering to the "suspended 
disbelief", they are rather kept in a foggy zone where the link between the character and the story is blurred.

The readers would always have this feeling that Offred was imagining things, not really experiencing them. Her permanently foggy state of mind as she 'tells' us her story, and the repeated use of the first person pronoun 'I' with the present simple tense exemplify for her being a semiconscious narrator: "I walk along the gravel path ... I open the white picket ... I know this man's name" (27). Whether it was reality or Offred was just imagining and dreaming, we are never sure. "I am dreaming that I am awake" (121), this recurring feeling that nothing has really happened highlights two things: the neurotic nature of the character, or the uncanny nature of everything that was happening around her to the extent that she escapes into denial. It can be denial of the isolated reality she lives, as much as of her own physical existence: "I can't think of myself, my body, sometimes, without seeing the skeleton: how I must appear to an electron. A cradle of life made of bones; and within hazards, rapped proteins, bad crystal jagged as glass" (122).

All the surrounding events in a community that seems to lack logic and reason for a character with her background; coming from a modern, democratic society, add to the hallucinations she suffers, and the confusion she causes: "The things I believe can't all be true, though one of them must be. But I believe in all of them ... this contradictory of believing seems to me right now, the only way I can believe anything" (116). She even relates the same story in different ways. For example, her physical encounter with Nick the Commander's driver is once said to have been a romantic, sensual encounter, another where it lacks emotions and is very harsh, leaving both of them suspicious of each other, and a third time in which she is "not sure how it happened; not exactly. All (She) can hope for is a reconstruction: the way love feels is always only approximate" (275). 
On the other hand, Offred is a fully developed, changing individual. She is fully aware of her 'past' and is capable of challenging her 'present'. Despite all the oppressive, detaching rules and regulations of Gilead, where everyone is framed into a distinctive and specific aperture in the hierarchal system that obscures and obstructs vision, speech and action, Offred is still capable of challenge through documentation. Despite all the Gileadean laws that criminalize individuality, she finds her voice and acknowledges its power by recording her story and her 'time'. This, besides her physically healthy well-being, and her fertile body - a significant issue for the plot- makes the readers identify with her, and consider her a string of reassuring hope for resistance, or even for survival in a chaotic world. Offred is never defeated. Her breaking discovery of an underground network of resistance, helped her pursue resistance through the best practice of her illegitimate love to the master's driver. 


\section{Conclusion}

Atwood can be considered as one of the pioneers and innovators in the field of transrealism. It is through this technique that she presents a futuristic view wherein she brings to light all her apprehensions about hegemony and world control. Conscious of her 'threatening reality', she produces a new content of a world suffering from the overwhelming experience of technological development wherein she presents a visualization of a divergent world and history. The outstanding combination of hypothetical fantasy and realistic representation is what transrealism is all about, and certainly what Atwood has achieved. The use of the different elements of transrealism such as time travel, the representation of milestone sophisticated ideological conflict -the 'gnarl' in the plot-, and the disoriented, neurotic character helped Atwood in demonstrating her worries about the future of the world. This depiction of time and its relation to space and the characters has helped Atwood cast the light on the past, present and future of the symbolic city of Gilead. It is only through the different mechanism of transrealism that the reader is able to depict the drastic backward and downward change that affected Gilead. Though the plot is mainly formed on 'reality' and the 'present' of Gilead, Atwood creates unpredictable situations that she twists to express her concerns and fears about the future. She does not advocate for the existing power structures or authorities, neither does she remark or highlight how these structures would lead to absurdities, but rather forces these structures into different logical setting and scenarios that allow the reader to measure the consequences. 


\section{Margins}

${ }^{1}$ Transrealism, according to an article publish in The Guardian, 24 October 2014, is not just a trend in today's literary production, but will be one of the major trends of the coming decades. It is surly more than this for many reasons which will covered in this essay. Obviously, the term transrealism is composed of two parts: trans and realism. The prefix which has been repeatedly recurring in the literary jargon, e.g. transcultural, transnational, etc., adds different levels of meaning to 'Realism', the well-established literary movement since the beginning the nineteenth Century, and which was developed through the succeeding century when it was combined with other determiners like magic realism, surrealism, etc.

2 This is where Transrealism and the genre of Dystopian Literature intersect. They both present a grotesque, grim picture of society due to political or social practices, and both intend to vex and scare the readers, as much as warn against such practices. Yet, Transrealism realizes these practices and calculates their consequences through unusual lens, where the authors, who reject all artificial representations or archetypal characterization, present their worries by mixing the fantastic and the realistic. They compel the readers to question, acknowledge, and find solutions for the threatening situations at hand. The apocalyptic environment created by the Covid 19 pandemic that has determined our reality and social interactions while revealing the morbid, dystopian conditions of this world, invites for a re-reading of the narrative discourse raised around this reality. In this case transrealism would not only be just another theoretical approach to the narrative discourse, but a reflection of today's reality: the isolation (imposed by social distancing), and ideological conflict between two or more world powers

${ }^{3}$ Qtd in Naderina cited below 
${ }^{4}$ Margret Atwood (1939 - ) is mentioned in the same article of The Guardian (ibidem) as a pioneer of transrealistic narrative.

${ }^{5}$ Will be henceforth referred to as (THT, $\mathrm{p} \#$ ) in the in-text citation

${ }^{6}$ The verse is taken from Acts (4:35 34). 


\section{Works Cited}

Atwood, Margaret. The Handmaid's Tale. London: Vintage Classics -Penguin Random House, 1985. Print

---, "Margaret Atwood on What 'The Handmaid's Tale' Means in the Age of Trump". New York Times. March 10, 2017. Web. February 20, 2020.

https://www.nytimes.com/2017/03/10/books/review/margar et-atwood-handmaids-tale-age-of-trump.html?auth=linkdismiss-google1tap

Augustine . Confessions. V.1: Introduction and Text. Oxford: Clarendon. 1992, p.154.

Auerbach, Erich, and Edward W. Said. Mimesis: The Representation of Reality in Western Literature. Princeton, N.J: Princeton University Press, 2003, p. 408. Print.

Broderick, Damian. Transrealist Fiction: Writing in the Slipstream of Science. Westport, CT: Greenwood Press, 2000. Print.

-- - "Transreal Nostalgia in a Time of Singularity". Journal of the Fantastic in the Arts 16 (1): 21-36. Spring 2005. Print.

Howells. C.A. "Margaret Atwood's Dystopian Visions: The Handmaid's Tale and Oryx and Crake." The Cambridge Companion to Margaret Atwood. Cambridge, UK: Cambridge UP, 2006, p. 163. Print.

Rucker, Rucker. "A Transrealist Manifesto". Enfield, Connecticut : The Bulletin of the Science Fiction Writers of America, 82, 1983.Web. 22 Feb. 2020, p.82. 
------. "Seek The Gnarl". Journal of the Fantastic in the Arts. Vol. 16. No. 61. The International Association for the Fantastic in the Arts. 2005. Print..

Nadernia, Vafe. "Transrealism: In Pursuit of Social Change and Collective Justice in Huxley's Brave New World". The Southern Asian Journal of English Language Studies. Vol.24 (2), 2018, pp. 71 - 81. Web. 3 March 2020. http://doi.org/10.1756/3L-2018-2402-06

Maso, Simon. The Rough Guide to Classic Novels. London: Rough Guides Limited, 2008. Print. Also qtd in Naderina, cited above.

Milena Škobo. "Transrealism - A modern Literary trend?". XIX International Scientific ConferenceAt: Sinergija University, Bijeljina. Nov. 2018, pp. 81-83. Web. 22 Feb. 2020.

https://pdfs.semanticscholar.org/cc51/5bfd2c602f4b0fac647 be985feae6129ea2e.pdf International Association for the Fantastic in the Arts 